\title{
THE PLACE OF SPACE IN FILM HISTORIOGRAPHY
}

Elsewhere I have argued that film studies as it has been practiced over the past thirty years or so has been haunted by the spectre of the empirical: a persistent ambivalence toward anything that exists outside the text and beyond the edges of the screen. This ambivalence has its roots in the conventionalism of the dominant strands of film theory in the I970s and, despite the field's moving into what some have called a 'post-theory' era, is sustained by teaching and analytical practices that owe a great deal to film's academic alliance (in the us, at least) with literary studies. ${ }^{\text {I }}$ One consequence of film studies' focus on text and textual interpretation has been the suppression or marginalizing of the spatiality of the experience of cinema.

However, new histories of movie exhibition, movie audiences, and the social experience of moviegoing along with the deployment of new technologies for reimagining and representing these histories suggest the need to reconstitute the object of film studies in relational, social, and, in fundamentally spatial terms. In this paper, I would like to suggest how an engagement with recent theoretical work on space and spatial representation might inflect such a re-spatialised notion of film and film history.

As I work toward my own account of the history of moviegoing in the American South and toward a database of moviegoing in North Carolina I am constantly confronted with the question: How can and should the experience of cinema by millions of people in tens of thousands of places over more than a century of moviegoing be represented? Although there are plenty of examples to the contrary in film history, we tend to associate the spatiality of cinema with particular places and thereby conflate the space of cinema with the places of cinematic exhibition. It is easy to think of the movie theatre as a fixed and empty space that contains the temporal experience of watching particular films. Spatial representation practices tend to accentuate the apparent inertness and ahistoricality of such places. Photo books of picture palaces are the representational correlative of the picturesque in landscape painting: showing them as empty, waiting, fixed in time, their superfluous architectural elaborations endowing the places of cinema with a timeless stability and materiality seemingly necessary to counter the accidental flux of performance and the continual mobility of 
bodies and movies through its space. Maps endow movie theatres with a representational permanence that transcends their existence in history.

\section{Rethinking space and the spatiality of cinema}

In For Space, geographer Doreen Massey calls for a theoretical destabilisation of space and a reconsideration of the implications of various modes of spatial representation. This entails rethinking representation as "no longer a process of fixing, but an element in a continuous production; a part of it all, and itself constantly becoming'. Representation thus conceived collapses the false separation between world and text. Representation is no longer understood as a mimetic outcome but 'an activity, a practice, an embedded engagement in the world of which it is a part. Not representation but experimentation.'

Massey proposes an alternative approach to space and spatial representation in terms of three deceptively simple propositions. First, that space is relational. It is the product of interrelationships and interactions extending from the intimate to the global. Second, it follows from a relational notion of space that space entails multiplicity. It is the sphere of 'coexisting heterogeneity'. And third, because space is a product of multiple, heterogeneous interrelationships, space is always in process. It is constructed through 'embedded material practices' that have to be carried out. Thus space is never closed. 'Perhaps we could imagine space', she writes, 'as a simultaneity of stories-so-far.' Here space clearly does not stand as the opposite of time or as its vessel. It is not the structure against which agency or history can be counterposed. Space is not the pre-existing place waiting for things to happen in it (or not); it is itself uniquely, unpredictably eventful. Any space that is conceivable is time-space, to use her term, both here and now, there and then, no matter the representational dilemmas that such a notion of space entails.

Such a view of space prevents us from reducing the space of cinema to the places of filmic exhibition and, further, from reducing all of those different places to a historically, culturally, or socially homogeneous 'scene' - a scene that is too easily eclipsed by merely turning out the lights in the movie theatre and substituting the super-sized represented space of the movie diegesis for the experiential space of moviegoing, and the singular temporality of the film's predetermined narrative for the much less predictable time/space of its reception. Understanding space as the sphere of coexisting heterogeneity means that the audience cannot be conceptually reduced to the spectator any more than space can be reduced to place. The experience of cinema does not exist outside the experience of space, and, as such it is the product of historically specific, embedded material practices - of performance, of display, of exchange, of architecture, of social interaction, of remembering, as well as of signification and cinematic representation. 
Viewed in this light, the film from the past that is available to the film historian today is itself a representation, with mimetic limitations that are different in kind but no less conceptually and historiographically consequential than those of the map or the photograph we rely upon to represent the location of long-gone picture palaces. As Michel de Certeau has put it, whatever else texts might signify, they signify and are always marked by the history of their own performance and 'the operations whose object they have been'. They 'indicate a social historicity in which systems of representations or processes of fabrication no longer appear only as normative frameworks but also as tools manipulated by users'. ${ }^{4}$ If space is the simultaneity of stories-so-far, any surviving filmic text is, if you like, an imagined simultaneity of all its spatialisations-so-far.

But it is much easier to flatten the incredible range and variety of cinematic experience over the past Iı years into an analytically distant horizon than to struggle to produce a theoretical and historiographic model of cinema that would take the multiform experience of cinema into account. As Massey points out, traditionally space has been associated with stasis and stability and (falsely, she would note) counterposed to time's association with agency and change. Film studies have been grounded by the (falsely) reassuring stability of the filmic text's temporal and hence historical repetition - what Philip Rosen, after Bazin, has termed 'change mummified'. Cinema, unlike literature or painting, has a temporal dimension, we say, but, unlike theatre, text time is always the same time. But just as space is always time-space, so time, including the temporality of cinema, is always space-time: each unspooling of a given film 'text' in time occurs in a particular place at a particular historical time; as the result of a particular conjunction of means, motive and agency; and in relation to a culturally and socially situated audience. As Della Pollock puts it, understood as 'tools' rather than formal constructs,

'texts charge history with the memory and promise of their own agency. They move readers and users into a space animated by conflict, possibility, efficacy, and exchange. In this space, texts ritually mark (and thus effect) and are marked (and thus signify) the social world enacted in, around, and through them."

One strategy for disciplining the spatiality of cinema has been to rearrange the multiplicity and heterogeneity of the spatial into a more orderly temporal sequence so that the always multiform spatiality of cinema is rendered historically bounded and containable. Particular, privileged, and, presumably consequential moments of cinema spatiality are foregrounded, rendering the rest of the history of cinema space a historiographic backdrop. And nowhere is this strategy more apparent than in the now canonical treatment of the nickelodeon in American film historiography. Accounts of moviegoing among recently-arrived immigrants in one part of one borough of one city in America between I907 and 
I9Io have accentuated the complex social and spatial aspects of the experience of cinema, and have regarded as relevant everything from the physical configuration of the theatre itself and its relationship to the surrounding neighbourhood to the role of moviegoing in the temporal and social organisation of immigrant women's everyday lives. But once the nickelodeon era is over, the complex and very specific spatiality of cinema recedes into a barely visible historiographic horizon - the victim of 'the sweeping ascendancy of the classical paradigm' of Hollywood cinema and its assumed normative mode of experience and reception. This is justified by the claim that classical Hollywood cinema's systemic interlocking of mutually reinforcing formal conventions, mode of spectatorship, audience, and viewing situation so reduce the "margin of unpredictability and autonomy' in the cinematic experience that there is little explanatory gain to be realised from constantly unpacking the empirical furniture. ${ }^{6}$

But I am not persuaded of this on empirical or theoretical grounds, and, indeed, my own modest research on moviegoing in the South confirms Massey's view that both history and space are open, not closed. There are always 'connections yet to be made, juxtapositions yet to flower into interaction, (...) relations which may or may not be accomplished'. Space is, indeed, a product of relations, she argues, but 'these are not the relations of a coherent, closed system within which, as they say, everything is (already) related to everything else'?

\section{Space, race, and moviegoing}

The inescapable spatiality and sociality of the experience of cinema becomes apparent when we look at the history of moviegoing in the American South. Here race - not class, gender, ethnicity, or immigration status - was the principal social axis along which the experience of moviegoing was organised from the beginning of cinema until the de-segregation of white theatres in the Ig6os. Most African Americans lived in the South - in I9Io, ninety percent of them and most of them lived in the rural South. Despite the image we have of the great migration of African Americans to Northern metropolitan centres in the early decades of the century, the black population of the South increased during that period, and almost every Southern town and city had a higher proportion of black residents than did any city outside the South. In I920, African Americans made up less than three percent of the population of New York City; they were fourty percent of the population of Birmingham, Alabama. One out three North Carolinians living in I920 was an African American. ${ }^{8}$

Race was the axis along which all space was organised in the South, particularly in all Southern towns and cities. The Supreme Court decision that gave the ultimate legal imprimatur to the racing of space in the South, Plessy v. Ferguson, was handed down three weeks after the first projected motion pictures were shown to a paying audience in New York City. For the first sixty years of film his- 
tory, all movies - wherever they were shown and by whomever they were viewed - were experienced as a part of the raced space of the South. Moviegoing inescapably came under the regime of state and local law, police power, and social custom commonly known as 'Jim Crow', which arose in the I89os to restrict the mobility, visibility, and political agency of African Americans.

The hyperterritoriality of Jim Crow, as one scholar has called it, was a reaction against the increasing visibility and mobility of African Americans in the rapidly growing towns of the American South at the end of the igth century. As places where blacks and whites, particularly black men and white women, might theoretically encounter each other and in the dark, movie theatres were especially sensitive spaces in every Southern town and city. In theatres that did admit blacks (and it is difficult to determine which they were), blacks were forced to sit in the balcony, and in many cases, purchase their tickets from a separate box office and reach their seats in what was called the buzzard's roost by way of a separate and frequently external set of stairs. The very architecture of Southern theatres relegated African Americans to the periphery of the scopic and experiential field of cinema for white viewers.

The space of cinematic experience for blacks and whites in the South was shaped by the legal status of that space: theatres were regarded as private property. Theatre managers had no obligation to serve anyone and had the power to exclude anyone for any or no reason. Southern movie theatres, then, illustrate the more general point about the relationship between space and the law made by a number of critical legal theorists - and a point that is congruent with the reconceptualisation of space that Massey advocates: that the law does not simply impose itself upon pre-existing legally empty space, but rather the legal apparatus actively produces, organises, and reorganises space. By the same token, the law does not exist apart from the 'local' places in which it takes on meaning through the material practices exercised in its name. ${ }^{9}$

But the racing of cinematic space under Jim Crow was not only disciplinary in nature, it was also generative. The legal 'right' of white theatre managers to exclude or restrict access to the movies by African Americans produced the space of the black theatre in the South and in other parts of the country as well. We know very little about black theatres - where they were, how many there were, who attended them, who owned and managed them, what kinds of films were shown. A I937 survey found only 232 black theatres out of nearly I7,000 operating movie houses. Most of them were in the South. ${ }^{10}$ Looking at the history of cinema from the perspective of the Jim Crow South, rather than the metropolitan North makes it impossible to ignore the spatiality of the experience of cinema for all moviegoers as well as the multiple and contested social meanings of cinema and moviegoing within every community. Race, in effect, imbues the very act of moviegoing with an overt political character in the South for more than sixty years. One of the extrapolated propositions that I would venture here, then, is that we really can't get at either the social meanings of cinema 
or the politics of moviegoing by watching movies alone, because both are produced through historically specific material practices to which surviving prints of old movies do not give us access.

\section{Space, moviegoing, and social identity}

Looking at the relationships among space, race, and cinema in the South has prompted me to rethink the relationship between moviegoing and social identity more generally. The notion of space I have outlined above 'chimes', as Massey puts it, with relational, process-oriented notions of identify formation and with the positing of experience and practice as mediating forces between an essentialist notion of fixed and already-constituted social identity, on the one hand, and identity as discursively constructed, on the other. In his discussion of the role of experience in identity, Dominick LaCapra argues that identity-formation might (...) be defined (...) as a problematic attempt to configure and, in certain ways, coordinate subject positions-in-process'. Among the subject positions involved in this process of identity formation, he says, are: 'sexuality, gender, family, language, nationality, ethnicity, class, race, [and] religion or secular ideology'. Each of these may be in any particular case multiple or internally divided. ${ }^{\text {II }}$

Film theory, of course, has had a great deal to say about subject positionalities and their negotiation but principally as a process occurring at the level of the unconscious and between the socially isolated, abstracted film spectator and the narrative and representational strategies of the abstracted filmic text. Respatialising the object of cinema studies prompts us to reconsider the sociality of cinema, and concomitantly, the role of a re-spatialised cinematic experience in the processes of identity formation. We might ask, for example: What extrapolated propositions can we make regarding the historical relationship between processes of identity formation and experiences of cinema? And, reciprocally, how would we need to reimagine the space of cinema in order to generate these propositions?

Making propositions regarding the relationship between identity formation and the experience of cinema must take into account the social experience of moviegoing not because the experience of moviegoing provides a 'context' for understanding the reception of all the thousands of films that were viewed by hundreds of millions (billions?) of moviegoers, but because the sociality of moviegoing is constitutive of the experience of cinema, and, hence, of its role in identity formation. This is made apparent to me by looking at the relationship between whiteness and moviegoing in the South. Legal scholar Cynthia Harris has proposed understanding whiteness in American history in terms of property. ${ }^{\mathrm{I}}$ Through the creation and enforcement of a separate and devalued cinematic experience for African Americans and their literal exclusion from the places of cinematic exhibition, Southern whites claimed the movies and movie- 


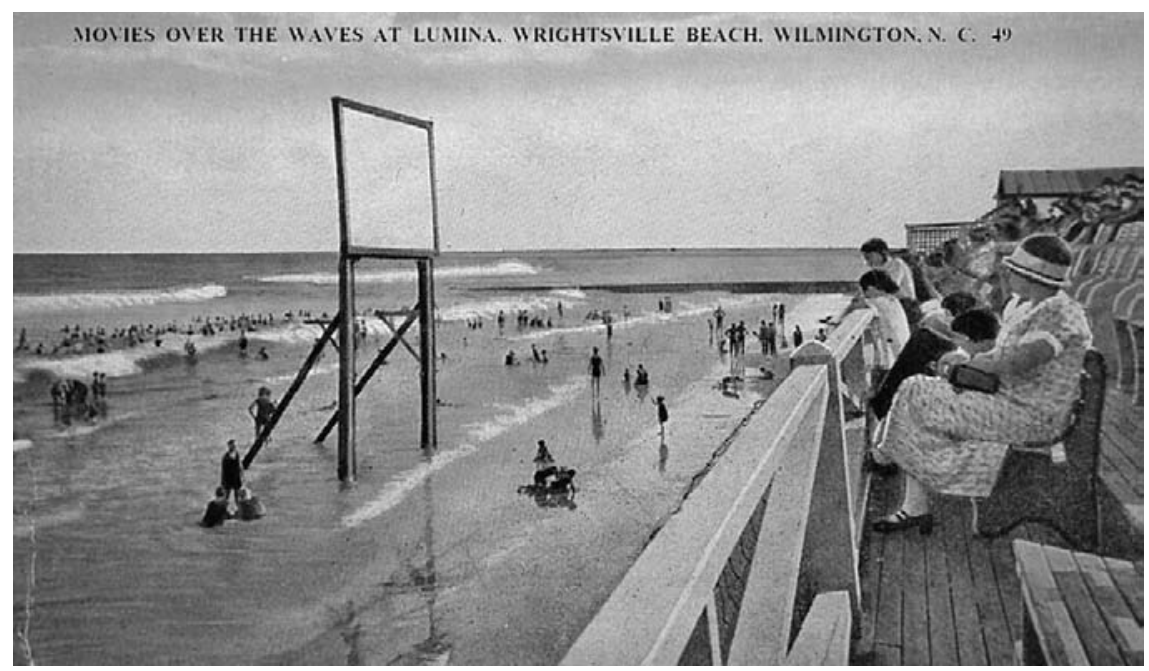

Lumina Park, Wrightsville Beach, North Carolina. Source: Courtesy of New Hanover Country Public Library, Wilmington, North Carolina

going as their property. When a black movie theatre opened in Fort Worth, Texas, in February I9II, a mob of Iooo white men and boys stoned the theatre and then began a 'systematic hunt' for any blacks they could find in the downtown area. Any black person who could not outrun the mob was 'set upon and beaten'. '3

Film studies have taken up social identity primarily in terms of class, race, ethnicity, gender, and sexual orientation. The history of moviegoing in the South suggests that other modalities of social identity were also important. Conversations with black and white senior citizens (including my own mother) about the place of movies in their lives alerted me to the role of religion as a dimension of social identity and its relationship to movies and moviegoing in the South. Where American film historiography has taken up religious belief and its relationship to the cinema, it has been primarily focused on institutional, ecclesiastical objections raised against narrative or representational practices in particular films - for example, the Catholic Legion of Decency's rating of individual films from morally unobjectionable to morally poisonous, and their campaign in the I930 to elicit pledges from Catholics that they would abstain from seeing the latter and from patronizing theatres that showed such films.

As a number of social historians have noted, religion in general and Christianity in particular played and continues to play a very important social role in the South, but the dominant strand of Christian belief was and is Protestant, not Catholic. Furthermore the Protestant sects that were dominant amongst rural and small-town Southerners and among workers in the rapidly industrializing urban South were those most suspicious of the effects and influences of cultural modernity. Although these sects were notoriously fractious and schismatic, what they shared was a belief in salvation as a purposive, transformative act, and a neo-Manichean world view which divided both space and behaviour into 
worldly (and hence sinful) and Godly. ${ }^{\mathrm{I}}$ Thus, for many conservative Christians, the spaces of commercial film exhibition remained morally and socially problematic for decades after movie theatres were established along main streets in Southern cities and towns. Religious ambivalence toward the movies probably contributed to South trailing far behind other regions in the per capita number of movie theatre seats and weekly movie attendance rates throughout most of film history in the us. As late as I966, an influential magazine published by the organisation headed by North Carolina evangelist Billy Graham and circulated to 200,000 Protestant ministers and laypersons, noted that 'Christians, as a rule, do not attend the movies'. ${ }^{\text {is }}$

Religious ambivalence over movies and moviegoing did not merely suppress moviegoing South, it was also generative of a number of interrelated practices - promotional, advertising, programmatic, civic - designed to anticipate and mitigate local moral concerns. These practices conditioned the experience of cinema throughout the South for non-Christians, Christians who had no moral qualms about going to the movies every day (except Sunday, of course), and for those who, like my mother, kept her childhood moviegoing a secret from her staunchly Baptist father, who, so far as my mother knows, never stepped inside a movie theatre in his life. For example, newspaper ads from towns in North Carolina show that theatre managers played up any film they could get with a religious theme, offered special screenings for church groups, allowed their theatres to be used for church services on Sunday mornings, and hosted visiting evangelists.

\section{Heterogeneous multiplicity}

The importance of reconceiving cinema in spatial and experiential terms is supported by recent work on the relationship between memory and history in film studies. As Dominick LaCapra has put it, 'What we refer to as experience is typically the memory of experience. ${ }^{\mathrm{I} 6}$ In her account of the role of movies and moviegoing in Depression-era Britain, Annette Kuhn discovered that the spatiality and sociality of the cinematic experiences persisted long after the memory of particular films had faded or blurred into each other. 'For the majority', she writes of her respondents, 'going to the pictures is remembered as being less about films and stars than about daily and weekly routines, neighbourhood comings and goings and organizing spare time. Cinemagoing is remembered, that is, as part of the fabric of daily life. ${ }^{\text {,7 }}$

Oral histories and memory work represent crucial archival resources for cinema studies. They are in some cases the only sources we have for understanding the spatiality and sociality of the experience of cinema in particular places at particular historical moments, and for understanding how moviegoing was or was not integrated into other practices of everyday life. As Kuhn's work demon- 


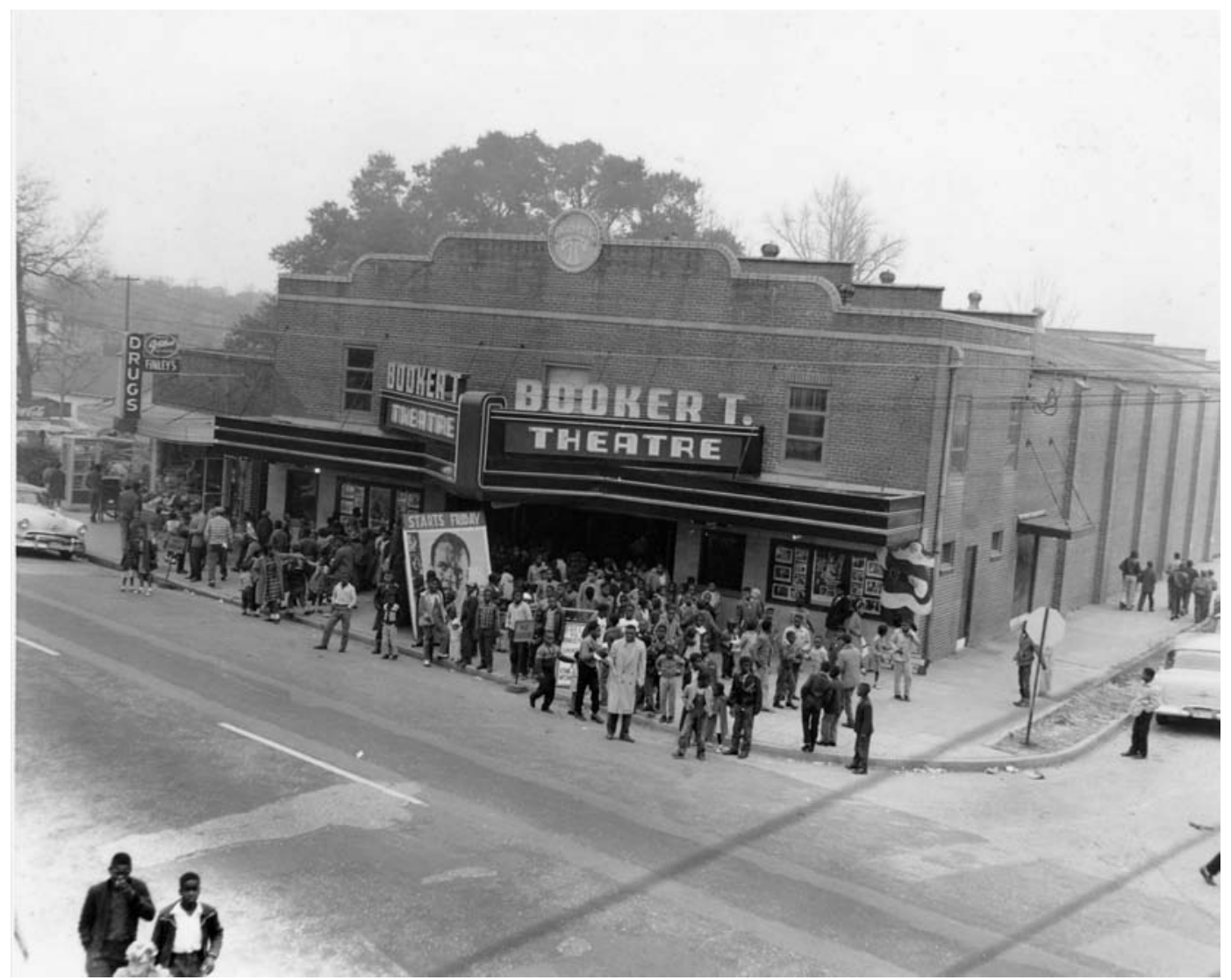

Booker T. Washington Theatre, Mobile, Alabama 1959. Source: Courtesy of University of South Alabama Library, Mobile, Alabama

strates, these approaches to film history allow us to explore the role of memory in relation to the experience of cinema. But recognizing the relevance of oral history and memory work to film studies has more profound historiographic and theoretical implications as well. They exponentially increase the number and variety of available film histories; they implicitly contest both the empiricist objectification of film history and the epistemological authority of the interpretive analyst. They explode any notion of a master narrative of cinema history into an ever growing surplus of petit récits - history, as Della Pollock puts it, as 'a somewhat humbler quilt of many voices and local hopes'.

A re-spatialised notion of cinema as the object of cinema studies would need to take on board Massey's first proposition: that space is 'the product of interrelationships'. To me this means understanding the experience of cinema as the product of multiple, heterogeneous interrelationships that extend from the person sitting next to you in the theatre to the distribution chain that links the time-space of your experience of a film to that of its production as well as to other 
people's experiences of cinema (including their experiences of that particular film). It also means that the space of cinema is related to and inseparable from the experience of other spaces. In the case of Kuhn's I930s moviegoers, the space of cinema was clearly related to the other spaces and practices that made up everyday life: work, shopping, domestic life, community, neighbourhood, et cetera. For African Americans and whites in the South, the spaces of moviegoing to which they were admitted or from which they were excluded have to be mapped upon other spaces in which sitting, standing, sleeping, eating, drinking, buying, and looking were or were not permitted, negotiated, or denied. For millions of black and white Southerners, the space of moviegoing was never very far away from the space of religious observance.

Foregrounding the complex, heterogeneous interrelationships that produce the space of cinema might prevent our unthinking adoption of what Massey calls the 'billiard ball' model of locality, whereby the local is produced through a process of geographic discontinuity and differentiation: this town rather than that one. Social and cultural specificity are then mapped onto each particular place, and the set into relationship with each other - like billiard balls striking each other on a pool table - with differences between them assumed to be the result of internal characteristics.

The local places of moviegoing, then, need to be re-presented not as autonomous, neutral, static places that contain audiences and movies, and that then can be 'compared' to other such places somewhere else, but as internally heterogeneous nodal points in a social, economic, and cultural cartography of cinema: intersections of overlapping trajectories, networks, trails, and pathways, whose identities are constructed through the connections and collisions that occur there.

\section{Circuits, pathways, and intersections}

Such a relational notion of the 'local' in film studies might also encourage us to pay more attention to those networks and pathways that connect them. As we all say in our introductory lectures on the economic history of cinema, the film business entails three distinct but interrelated processes: production, distribution, and exhibition. But two of these have received much greater elaboration in film studies than the other. Production has been unfolded into studies of authorship, stardom, style, industrial and creative organisation, and technologies. Exhibition opens out to studies of theatre architecture, management and performance, audiences, reception, fan culture, and moviegoing. For the most part, distribution has not been as intellectually fertile as the two economic aspects of cinema that it connects. And yet two of the most notable and enduring characteristics of cinema as a cultural form have been its mobility and geographic reach. Distribution involves not just the physical transportation of cans of films, but a 
much more complex economic, cultural, technological, and social circulation and exchange - of people, technologies, ideas, stories, images, identities, places, practices, and values.

In us film historiography, just as we have tended to associate the spatiality of cinema with a particular and bounded moment in film history, so we have tended to emphasise the peripatetic nature of cinema as a feature of its primitive phase, after which the complex process of cinematic circulation described above is often unproblematically collapsed into a systematic, rationalised distribution process as cinema matures. And yet, evidence accumulates that the circulation of cinema has always been a complex, multi-layered, and varied process. Itinerancy remained an important means of circulating the experience of cinema in many parts of the United States (and, I suspect many other countries as well), long after the establishment of dedicated movie theatres and the vertical integration of Hollywood studios.

The term 'distribution' suggests a uniform, temporally and spatially closed circuit regulated by the corporate logics of the film studios and the complex hierarchies of business practice: coordinated release schedules, runs, zones, and clearances. But particularly outside the largest cities in the us (and keep in mind that in I9Io, two-thirds of all Americans lived outside of cities of any size), the circulation of cinema was not nearly so neat or uni-directional. We are only now beginning to appreciate the full significance of what Barbara Klinger calls in her new book, 'extra-theatrical' cinematic experiences. ${ }^{\mathrm{I}}$ Movies were shown throughout the us and throughout the first half of the century in many places other than movie theatres: in school auditoriums, church basements, community centres, town halls, union halls, Masonic lodges, libraries, private homes, amusement parks, on riverboats, and projected on the sides of buildings in the summer time. Other circuits of cinematic exchange and experience crisscrossed those laid down by Hollywood (or Berlin, or London, or Sydney). Multiple federal and state departments and agencies produced and distributed films, again, particularly though not exclusively in rural areas. Religious denominations, labour unions, and corporations all made and distributed movies, creating cultural pathways that connected them with local unions, churches, businesses, and civic organisations.

The history of the mainstream film industry in the us has almost from its beginning been shadowed by its underground other: the pornographic film industry, whose annual turn over today approaches that of its more culturally respectable cousin. Except for a relatively brief period in the I960s and I970s, however, movie theatres would not appear on the network map of pornographic film culture. Stag films or blue movies, as they were called in the States, circulated along different economic, social, and cultural pathways, the intersections of which were not theatres but veterans' halls, fraternal lodges, men's clubs, and other sites of male homosociality, which became occasional sites of film exhibition when 'smokers' or stag nights were organised. 
Recent research has also demonstrated that national and transnational networks of cinematic circulation were overlaid by more local or regional networks of both production and distribution. In North Carolina a studio photographer named H. Lee Waters purchased a sixteen millimetre movie camera in I936 and over the next six years shot, edited, distributed, advertised, and exhibited what he called 'movies of local people' in II 8 small towns in North Carolina and adjacent states. Each film was shown only in the same town in which it was shot and only for a few days at the local movie theatre. ${ }^{\text {I9 }}$ In his work on the Marzen family and their production and exhibition of local films in Trier, Uli Jung has worked to correct a major blind spot in early German film historiography with regard to local films, and recent work on Mitchell and Kenyon has called attention to the production and circulation of early local films in Britain. ${ }^{20}$ Conceiving of the space of cinema not as a set of geographically dispersed sites but cultural, social, and economic networks encourages film scholars to trace both the continuities and the discontinuities involved in the experience of cinema in what we might call the post-cinema era, or, at least, what I have called the post-Hollywood era. ${ }^{2 \mathrm{I}}$ The era when most people in the us experienced most movies in a movie theatre and when Hollywood was primarily in the business of making and circulating films among movie theatres has been over for at least fifteen years. Hollywood's own technological, economic, marketing, and legal practices have helped to displace the movie theatre from the centre of the experiential map of cinema for most Americans and for hundreds of millions of people around the world, while new technologies of representation, reproduction, display, sharing, and distribution have both laid down new global circulation pathways and exploded the once at least theoretically delimitable spaces of moviegoing into an as yet literally unrepresentable heterogeneous multiplicity.

Last summer I did some teaching in Shanghai. The graduate student assigned as my translator and local guide was very disappointed to learn that he had a much greater familiarity with current American movies than I did. He saw everything on his computer - either as DVDS (purchased for the equivalent of around eighty cents at a shop around the corner from the university within weeks of a film's us premiere) or as files downloaded for free from P2 P sites. Last year some 2 billion DVDs were sold in China, 95\% of them unauthorised copies of Hollywood films. 'When was the last time you saw a movie in a movie theatre', I asked him. 'About ten years ago', he replied.

The ironies and paradoxes here are multiple, beginning with the fact that what he 'saw' and 'heard' as a Hollywood movie on his DvD player or computer was, in fact, a recording of its being experienced by an unknown other moviegoer, sitting in a movie theatre in Los Angeles or New Jersey using a digital video camera concealed in a popcorn box - complete with coughs, whispers, involuntary camera movements and other reminders of the social and aleatory nature of all cinematic experiences as well as the spatiality of those experiences. If cinema 
studies is to remain viable as a field of inquiry, it must be able to define its object of study in such a way that my Shanghai graduate assistant's experience of cinema - with all its peculiarities, ironies, and paradoxes intact-is at its conceptual centre.

I See R. C. Allen, 'Relocating American Film History: The "Problem" of the Empirical', Cultural Studies, vol. 20, n. I, February 2006, p. 48-88.

2 D. Massey, For Space, London 2005, p. 26-28.

3 Ibid., p. 9 .

4 M. de Certeau, The Practice of Everyday Life, Berkeley I984, p. 2I; quoted by D. Pollock, Exceptional Spaces: Essays in Performance and History, Chapel Hill I998, p. 2I.

5 Ibid., p. 2I.

6 M. Hansen, Babel and Babylon, Cambridge I991, p. 90-125.

7 Massey, For Space, p. II.

8 Fourteenth Census of the United States Taken in the Year 1920, volume I-IV, "Population", Washington DC I92I-23, p. 59 .

9 N.K. Blomley, Law, Space, and the Geographies of Power, New York I994, p. 45-46.

Io Motion Picture Herald, July Io, I937, cited in M. Johnson, 'Seeing Yourself as Others See You in the Films of H. Lee Waters', M.A. Thesis, University of North Carolina at Chapel Hill, 2005, p. 70.

II D. LaCapra, 'Experience and Identity', in: L. Martin Alcoff, M. Hames-Garcia, S. P. Mohanty and P. M. L. Moya (eds.), Identity Politics Reconsidered, New York 2006, p. 228-245.

2I C.I. Harris, 'Whiteness as Property', Harvard Law Review, vol. Io6, n. I707, I993.

I3 'Ft. Worth Mob Harries Negroes', Atlanta Constitution, 28 February I9II, p. I.

I4 On the role of religion in the South, see E.L. Ayers, Southern Crossing: A History of the American South, 1877-1906, Oxford I995; L.H. Larsen, The Rise of the Urban South, Lexington I985; and R.B. Spain, At Ease in Zion: Social History of Southern Baptists, 1865-1900, Nashville I96I.

I5 J. Melville White, 'The Motion Picture: Friend or Foe?’, Christianity Today, 22 July I966, p. 9-II. Changes in the evangelical stance toward the movies in the I960s and I970s are discussed by Shanny Luft in his unpublished 2004 paper, 'To Discern Between Good and Evil: Christianity Today and the Movies'.

I6 LaCapra, 'Experience and Identity', p. 240.

I7 A. Kuhn, An Everyday Magic: Cinema and Cultural Memory, London 2002. The u.s edition is: Dreaming of Fred and Ginger: Cinema and Cultural Memory, New York 2002.

I8 B. Klinger, Beyond the Multiplex: Cinema, New Technologies, and the Home, Berkeley 2006.

I9 See Johnson, 'Seeing Yourself as Others See You in the Films of H. Lee Waters'.

20 U. Jung, 'Local Views: A Blind Spot in the Historiography of Early German Cinema', Historical Journal of Film, Radio, and Television, vol. 22, n. 3, 2002, p. 253-273; V. Toulmin, P. Russell and S. Popple, The Lost World of Mitchell and Kenyon, London 2004.

2I R.C. Allen, 'Home Alone Together: Hollywood and the "Family Film"', in: M. Stokes and R. Maltby (ed.), Identifying Hollywood's Audiences: Cultural Identity and the Movies, London I999. 